\title{
Novel immunogenomic insights of corona virus disease (COVID-19): Available potential immunotherapeutics, current challenges, immune cell recognition and ongoing managerial strategies
}

\author{
Kabeer Haneef ${ }^{1, *}$, Muhammad Umer Asghar ${ }^{1,2,3}$, Ashiq Ali $^{4}$
}

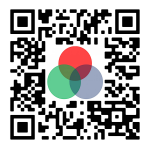

Use your smartphone to scan this QR code and download this article

\begin{abstract}
${ }^{1}$ Institute of Microbiology (IOM), University of Agriculture Faisalabad (UAF), Pakistan

${ }^{2}$ National Institute for Biotechnology and Genetic engineering (NIBGE), Faisalabad 38000, Punjab Pakistan

${ }^{3}$ Pakistan Institute of Engineering and Applied Sciences (PIEAS), Nilor,45650, Islamabad, Pakistan

${ }^{4}$ Department of Pathology, Faculty of Veterinary sciences, University of Agriculture Faisalabad-38000, Pakistan

Correspondence
\end{abstract}

Kabeer Haneef, Institute of Microbiology (IOM), University of Agriculture Faisalabad (UAF), Pakistan

Email: Kabeerhaneef16@gmail.com

\section{History}

- Received: Jul 22, 2020

- Accepted: Aug 22, 2020

- Published: Aug 312020

DOI : 10.15419/bmrat.v7i8.620

\section{Check for updates}

\section{Copyright}

(c) Biomedpress. This is an openaccess article distributed under the terms of the Creative Commons Attribution 4.0 International license.

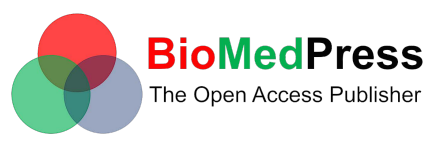

\begin{abstract}
The emerging Corona virus strain (severe acute respiratory syndrome corona virus-2 (SARS-CoV-2)) harbors intricate pathogenicity in the development of corona virus infection (COVID-19)-induced pneumonia and subsequently ameliorates lung infection. Genome sequence and phylogenetic interventions reveal proximal resemblance of corona virus strain COVID-19 with severe acute respiratory syndrome (SARS), transmittable to bats, suggesting similar primary hosts in the spread of infection. However, potential rapid human-to-human transmission has caused therapeutic challenges in treating a wide range of humans suffering from corona virus all over the world. However, up to now, no direct vaccines or antiviral drugs are available to treat COVID-19. Previously designed antiviral drugs and convalescent plasma are undergoing investigations as treatment for COVID-19 infected patients. Therapeutic challenges with regards to COVID-19 have prompted scientists to develop fruitful remedies to combat the pathogen. In this review, we address the role of current ongoing therapeutic strategies, immunogenomics, and complex mechanisms of adaptive immune system (B and T cells) to respond to viruses. Furthermore, we illustrate the current challenges in the treatment of COVID-19, managerial strategies, and ongoing and future perspectives.

Key words: Covid-19, immunogenomics, treatment modalities, adaptive immunity, management strategies
\end{abstract}

\section{INTRODUCTION}

Coronaviruses, especially severe acute respiratory synsdrome-2 (SARS-CoV-2), are minute singlestranded micron sized RNA particles ${ }^{1}$, harboring intricate capability to induce lung infection and pneumonia in humans ${ }^{1}$; they are ordered in the Coronaviridae family ${ }^{2}$. Previous corona virus outbreaks in China (Guangdong) have revealed their potential capability to induce intestinal and lung infections ${ }^{3}$. However, none of the quarantine measures were adopted in the 2002 and 2003 outbreaks $^{4,5}$. Similarly, a decade later, Asian countries experienced another deadly outbreak of middle east respiratory syndrome (MERS) virus, belonging to MERS-CoV ${ }^{6,7}$. Thus, research community was engaged and therapeutic modalities were followed to combat MERS. With the emergence of the new deadly outbreak of novel coronavirus COVID-19, there was experience and knowledge about the meticulous capability of genome mutation of the virus $^{8,9}$. Different inculcations revealed that mortality parameters are dependent on physical health, age, immune mechanism, and gender discriminationranging from $0.3 \%$ to $15 \%{ }^{10,11}$.

The human body is bombarded via pathogens and responds by sophisticated mechanisms to develop immunity ${ }^{12,13}$. Innate immune cells (e.g. macrophages and dendritic cells) and adaptive immune cells (e.g. $\mathrm{B}$ and $\mathrm{T}$ lymphocytes) work in close proximal association to produce potent neutralizing antibodies with stringent potential to neutralize viruses and develop immunity ${ }^{14,15}$. Following invasion of pathogen-associated molecular patterns (PAMPs) and viruses, antigen-presenting cells (APCs) like macrophages and dendritic cells respond quickly, processing and presenting peptide antigens to $\mathrm{B}$ Lymphocytes through major histocompatibility complex (pMHC) molecules ${ }^{16,17}$. However, the way the immune system discriminates between the types of pathogens remains poorly understood. Typically, major histocompatibility complex- 1 (pMHC1) and pMHC-2 molecules provide efficient potential to discriminate through substantial mechanism of antigen presentation ${ }^{18,19}$. In addition, recent evidence from COVID-19 investigations have suggested 
that mutational interventions interlinked with pMHC molecules could be crucial to devastate COVID-19 induced pathogenicity and suggest pMHC as a suitable candidate for drug discovery ${ }^{20,21}$.

Considering the structural complexity features of COVID- $19^{22}$, currently no promising therapeutic strategies are available. However, several antiviral drugs previously employed for MERS-CoV and SARS-CoV are ongoing as therapeutic remedies after clinically-approved applications ${ }^{23,24}$. Remdesivir, alone or in adjacent combination with chloroquine and interferon-beta (IFN- $\beta$ ), has been proven promising against SARS-CoV-2, and thus has been suggested as an available promising therapeutic strategy ${ }^{25-27}$. However, recently, several groups have actively reported on the efficiency of plasma-derived monoclonal antibodies from blood of COVID-19 infection-recovered patients, and have suggested the use of such antibodies as passive immunization therapy ${ }^{28,29}$. However, considering the aforementioned strategies, there is a dire need to develop more potent antiviral drugs to target viral proteins, nucleotides, capsids and nucleosides.

\section{MORPHOLOGIC AND KEY GENOME PROSPECTIVE FEATURES OF COVID-19}

Coronaviruses - especially SARS-COVID-19 (of the Coronaviridae family) - have a morphologic configuration which shows minute single-stranded, enveloped particles ranging in size from $150-160 \mu \mathrm{m}^{30}$. Further evidence have suggested that surface-flanked $S$ proteins as well as matrix and nucleocapsid proteins harbor stringent pathogenicity factors to devastate immune mechanisms ${ }^{31}$. COVID-19 virus particles additionally encodes for hemagglutinin (HA) proteins, revealing key genome differences with other strains $^{10,24}$. Considering sequence interventions and key genome identity features, COVID-19 has been revealed to show proximal resemblance with SARS$\mathrm{CoV}$, in contrast to MERS-COVID ${ }^{10}$. In addition, surface-anchored glycoproteins and $\mathrm{S}$ proteins grant discriminating potential, thereby suggesting them as suitable therapeutic candidates to target surfaceflanked $S$ components. In addition, amino acid sequence interventions have revealed that $S$ protein is divided into two parts: S1 (which facilitates COVID19 entry into the human body), and S2 (which interferes with the host immune system) ${ }^{24}$. Similarly, additional evidence have suggested that COVID-19 shows resemblance to SARS-COVID in terms of S1, i.e. with respect to amino acid sequence interventions $^{32}$. However, considering the key genome identity features, it is interesting and noteworthy that both strains gain access to invade the hosts ${ }^{33}$. Structural and conformational analyses have already revealed that human angiotension-2 (hACE-2) receptor provides an intricate attachment site to trigger COVID19 while facilitating SARS-COVID entry into the host (Figure 1) ${ }^{34}$.

\section{MECHANISMS OF THE IMMUNE SYSTEM IN RESPONSE TO VIRUS PARTICLES INVADING THE BODY AND THE ASSOCIATED IMMUNOPATHOLOGY}

The human immune system, i.e. innate and adaptive immunity, works in close proximal coordination to produce potent neutralizing antibodies to combat virus particles invading the body ${ }^{35}$. Aberrant host immune mechanisms could initiate the onset of immunopathology with subsequent potential to devastate immune mechanism ${ }^{36}$. However, evidence have suggested that COVID-19, through human angiotensin converting enzyme 2 (hACE2) receptor, transduces genomic material into the host and mediates pattern recognition receptors (PRRs), especially toll-like receptor (TLR)-3, TLR-7 and TLR8 , which potentially detect persistence of viral particles in the cytoplasm ${ }^{37}$, thus mediating a series of immune mechanisms. Likewise, several PRRs like melanoma differentiation gene-5 (MADG-5) and retinoic acid inducible gene 1 (RIG-1) have been identified for their ability to detect cytosolic viral pathogen interlinked molecular patterns (PAMPs), triggering a proximal series of events ${ }^{38,39}$. However, some prescribed activities initiate signaling cascade events through proximal recruitment of signaling and adaptor proteins, including mitochondria conceived antiviral protein (MAVS), stimulant of interferon gene (STING), and IFN- $\beta$, to trigger downstream series of proximal events ${ }^{24}$. However, these activities together can further lead to the recruitment of adaptor protein MyD88, which has stringent potential to regulate transcription factors, and subsequently recruits interferon-1(IFN- $\alpha / \beta)$ molecules, and proinflammatory cytokine candidates as key players to combat infection ${ }^{40}$.

\section{CYTOKINE BOMBARDMENT AGAINST COVID-19}

Following viral infection, the coordinated immune system shows an intricate capability to produce proinflamatory cytokines ${ }^{41}$ and induce a specific lineage 


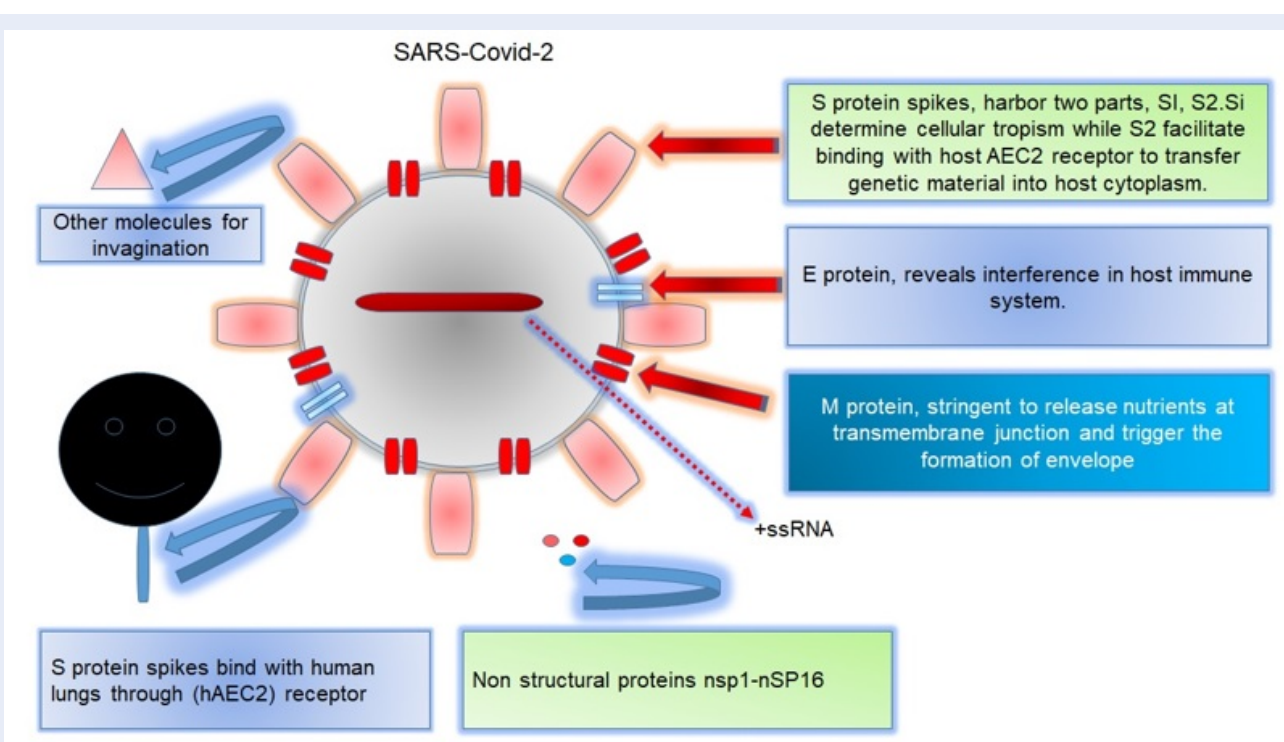

Figure 1: Morphological features of SARS-CoV-2. Structural features revealed that SARS-CoV-2 uses S protein spikes to adhere to host angiotensin converting enzyme (hAEC2) and induces lung infection and pneumonia. $E$ structural protein reveals interference with host immune system. M protein triggers the release of nutrients at the junctional interface. Small dots revealed 16 nonstructural proteins ranging from Nsp1-Nsp16.

of $\mathrm{T}$ cells, including $\mathrm{CD}^{+}$and $\mathrm{CD}^{+}{ }^{+} \mathrm{T}$ cells, as well as induction of other danger-alarming signals to potentially fight the virus ${ }^{42}$. Following infection, and injury mechanism, the pro-inflammatory cytokine milieu recruits innate immune cells, especially macrophages and granulocytes, at virus accumulated localized periphery to combat infection ${ }^{43}$. However, collectively, these efforts recruit macrophages, thus resulting in macrophage-collecting syndrome (MCS) to devastate infected tissues ${ }^{44}$. Similar inculcations have already revealed that cytokine release syndrome (CRS) is associated with the onset of morbidity leading to devastation and severity of disease ${ }^{45}$. Interestingly, interleukin (IL)-6 has been reported as a hallmark of MERS-COV infection ${ }^{46}$. Recent investigations have suggested that elevated serum concentrations of IL- 6 and other pro-inflamatory cytokines result in the onset of respiratory distress and failure. Likewise, a decrease of blood cells (lymphopenia) cannot be considered as a biomarker for COVID19 diagnosis because of its correlation with HIN1 influenza outbreak in $2009^{46}$. Thus, the elevated serum interleukin level resulting in the onset of other reactive proteins is fundamental to better deciphering proximal association in terms of disease progression. Similar interventions have suggested that $C$ reactive protein (CRP) may serve as a prognostic factor which has a contributing pivotal role in corona virus related pathologies. In addition, cytokines induced during
CRS could be targeted with high-affinity antibodies to treat COV-19 patients, and have been suggested as suitable clinical drug targets ${ }^{46}$.

\section{OVERVIEW OF ONGOING THERAPEUTIC STRATEGIES AGAINST SARS-COV-2}

In spite of progressive cutting-edge technologies and substantial efforts, there is currently no direct evidence of intricate therapeutic strategies to treat corona virus (COVID-19) patients ${ }^{37}$. Following infection, several healthcare organizations initially used adjacent combination of antiviral and antibacterial drugs (interferon alpha-nebulization) to reduce viral load ${ }^{27}$. Antiviral drugs (Remdesivir), alone or in adjacent combination with antibacterial (Arbidol chloroquine salts) and antimalarial drugs, have undergone ongoing tests but have been unable to achieve complete therapeutic efficacy ${ }^{25,26}$. In addition, Remdesivir- together with interferon- $\beta$ - have been clinically proven to be effective at stopping SARS-CoV-2 replication ${ }^{47,48}$. In contrast, in spite of recovery of Covid-19 patients, higher incidences of side effects (including mental stress, and epigastric stress together with cardiac and renal complications) have been observed in elderly patients ${ }^{49}$. Similarly, in China, several Chinese traditional medicines have been administered with antiviral and antibacterial drugs to treat SARS-CoV-2 infected patients ${ }^{48}$. 
Plasma-isolated antibodies from blood of convalescent patients have been proven effective to neutralize COVID-19 virus, suggesting that the plasma represents an efficient and available therapeutic strategy $^{49}$. Several experimental inculcations revealed the therapeutic efficacy of monoclonal antibody CR-3022 to bind with the spike glycoprotein of SARS-CoV-2, suggesting it can be an efficient therapeutic strategy in the future, possibly in combination with antibodies $^{50}$. In spite of the dilemma of therapeutics, vaccines are still considered the most efficient formulation to immunize people for prevention and to treat corona virus patients ${ }^{51}$. However, in spite of progressive efforts, there are still no vaccine candidates which have been clinically approved yet to generate immune efficacy ${ }^{51}$. Following a substantial increase in SARSCoV-2 -induced mortality, several notable pharmaceutical companies and research centers around the globe have been trying to configure a vaccine; more time is required to achieve this goal which can lead to therapeutic efficacy ${ }^{52}$. In addition, recently, PicoVac vaccine has been formulated in China and has shown some effectiveness against 10 strains of SARS-Covid$2^{24}$.

\section{POTENT ANTIVIRAL STRATEGIES}

From phylogenetic interventions and key genome resemblance features of SARS-CoV-2 with SARSCOVID and MERS, previously designed antiviral drug Remdesivir and ribavirin have been under ongoing investigations for their potential therapeutic efficacy $^{53}$. Following COVID-19 infection, some health organizations have worked together with research centers and declared adjacent treatment with chloroquine and antiviral drug Remdesivir. Interestingly, so far, Remdesivir has been a broad spectrum antiviral drug and currently tested in major countries including America, Europe and UK; it has been declared as a promising therapeutic strategy to treat SARS-CoV2 infected patients (Table 1$)^{26}$. Likewise, several broad spectrum antiviral drugs, including Ribavirin, Lopinavir, Ritonavir, Favipiravir and Umifenovir, and anti-malarial drugs (such as chloroquine and hydroxychloroquine) are being investigated in the treatment of SARS-CoV-2 infected patients ${ }^{34,54-57}$.

In addition, major investigations are ongoing to release large-scale slots for the betterment of humanity ${ }^{53}$. Specified targeted therapeutic interventions did not reveal obvious side effects, suggesting a comprehensive treatment modality. Thus, based on genome identity features, comprehensive drug modalities could be designed for proximal candidates of COVID-19, SARS-CoV-2, and MERS-COVID ${ }^{65}$.
Furthermore, suitable drug candidates could be designed to target viral nucleotides, nucleosides and nucleic acids ${ }^{53,54}$. Moreover, structural investigations of surface glycoproteins (S) could offer deeper understanding for the development of potent antiviral drugs against COVID-19. More importantly, with respect to COVID-19, viral entry requires intricate cleavage at S1/S2 junction; thus, potent monoclonal antibodies could be targeted to stop S1 cleavage with subsequent application of inhibitors to stop S2 phase of infection $24,27,28$. Indeed, following SARS-COVID-19 infection in China, clinicians employed other antiviral drugs including Lopinavir/Ritonavir (LPV/RTV), which showed mild improvement only in patients harboring initial stage of symptoms within 12 days (Table 1) ${ }^{53}$.

\section{PHYLOGENETIC GENOME INTERVENTIONS AND KEY VARIATIONS IN SARS-COV-2}

Previously reported coronaviruses (e.g. SARS, MERS, etc.) show $80 \%$ genome identity features with SARS$\mathrm{CoV}-2^{24}$. Surface-flanked proteins are potentially encoded by four genes ( $M, N, S$, and E), each with stringent capability to encode respective proteins including membrane proteins, nucleocapsids, surface proteins and envelope proteins, respectively, to mediate specified events ${ }^{24}$. Sixteen nonstructural proteins and pplab are encoded by large gene segment Off1 ab of SARS-CoV-2 ${ }^{66}$. According to sequence interventions, the phylogenetic tree genome of SARS-CoV-2 seems close to that of SARS coronaviruses ${ }^{24}$. In addition, genomic sequence interventions to decipher the variations in genome features have been fundamental to better decipher strategies to generate more effective drug candidates. Genome variation analysis revealed that SARS-CoV-2 shows an absence of gene segments $8 \mathrm{a}$ and $8 \mathrm{~b}$, in contrast to SARS-CoV genome (Figure 2) ${ }^{66}$. In addition, surface glycoprotein intervention reveals that SARS-CoV-2 surface proteins are a mixture of bat and other coronaviruses' proteins ${ }^{67}$. Additionally, fluorescent studies conducted by some groups have reported that both SARS-coronaviruses and SARS-CoV-2 use the same proximity of ACE2 enzyme for attachment to lung ${ }^{38}$. Genome mutation interventions have demonstrated that N50IT mutations in spike $S$ proteins trigger their intricate binding with host receptors (Figure 2) ${ }^{68}$. 
Table 1: Overview of available potential antiviral strategies to treat nSARS-CoV-2

\begin{tabular}{|c|c|}
\hline Antiviral drug & Mode of activities and mechanism \\
\hline Remdesivir & $\begin{array}{l}\text { GS5734 (inhibitor of nucleoside), attained worldwide attention and frequently in use to treat } \\
\text { COVID-19 infected patients. Remdesivir also have been employed to induce premature ter- } \\
\text { mination of Ebola viruses. Invivo studies revealed its potential to mitigate viral load in lungs } \\
\text { pneumonia (Y. Cao et al., } 2020^{25} \text {; Y. Wang et al., } 2020^{4} \text { ). }\end{array}$ \\
\hline Umifenovir & $\begin{array}{l}\text { Non-nucleoside immune potentiating antiviral drug, employed by Russia and China for the treat- } \\
\text { ment of many corona virus pathologies and influenza prophylaxis. During current epidemic Chi- } \\
\text { nese government recommend } 200 \mathrm{mg} \text { dose thrice a day to treat COVID-19 patients (Costanzo et } \\
\text { al., } 2020^{54} \text {; Lian et al., } 2020^{58} \text { ). }\end{array}$ \\
\hline Favipiravir & $\begin{array}{l}\text { Favipiravir currently recommended in china against COVID-19 infection. Its clinical efficacy } \\
\text { proved effective than ritonavir/ritonavir. In addition, Bangkok government declared its mas- } \\
\text { sive applications against COVID-19 in march. Invivo investigations declared its efficacy against } \\
\text { SARS-CoV-2 and MERS on Vero cell lines (Cai et al., } 2020^{59} \text {; C. Chen et al., } 2020^{57} \text { ). }\end{array}$ \\
\hline Ritonavir/Liponavir & $\begin{array}{l}\text { Alone or in adjacent combination with interferons have been recommended at } 200 \mathrm{mg} / 50 \mathrm{mg} \text { dose } \\
\text { rate twice a day. Lponavir and ritonavir have been previously used for the treatment of retro- } \\
\text { viruses, are recommended efficient against COVID-19 (B. Cao et al., } 2020^{60} \text { ). }\end{array}$ \\
\hline Hydroxychloroquine & $\begin{array}{l}\text { Potential inhibitor of heme polymerase with potent antiviral strategies against SARS-CoV-2, in- } \\
\text { fected patients have been approved clinically to achieve therapeutic efficacy. Triggered endoso- } \\
\text { mal pH to block SARS-CoV-2 fusion events. In addition, chloroquine and hydroxychloroquine } \\
\text { are used for the treatment of lupus nephritis and rheumatoid arthritis (RA). Likewise, invivo in- } \\
\text { vestigations have declared its antiviral and immune modulation activities (Colson et al., } 2020^{56} \text {; } \\
\text { Ferner \& Aronson, } 2020^{61} \text {; Gautret et al., } 2020^{62} \text { ). }\end{array}$ \\
\hline Ribavirin & $\begin{array}{l}\text { Broad spectrum antiviral drug ribavirin Inhibit mRNA capping and synthesis of viral RNA. In } \\
\text { addition, Investigations have proven effective against MERS, SARS, and SARS-CoV. However, } \\
\text { proper dose evaluations require further research to maintain clinical efficacy (Elfiky, 2020 } \\
\text { Taber et al., 1983) }{ }^{64} \text {. }\end{array}$ \\
\hline
\end{tabular}

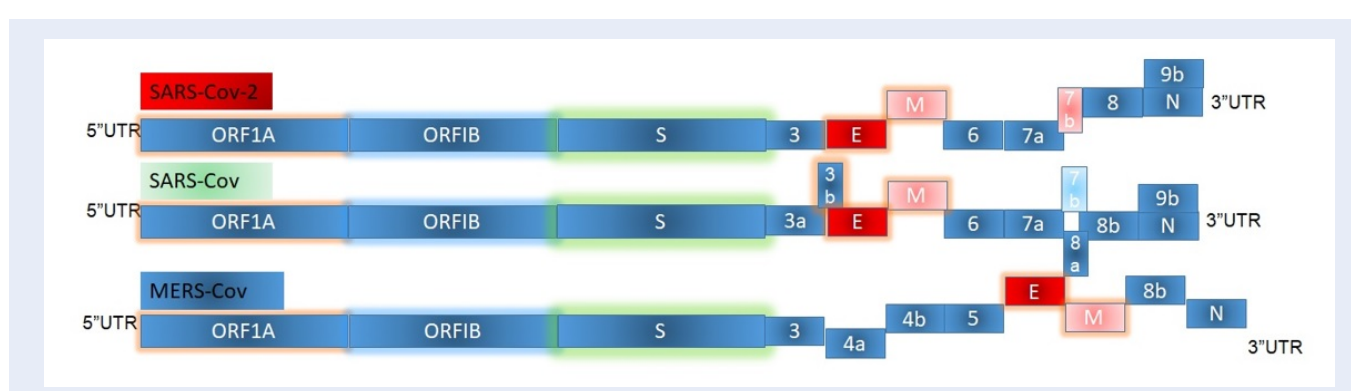

Figure 2: Novel genome variation features of SARS-CoV-2 from SARS-CoV and MERS. Coronaviruses (SARSCoV-2, SARS-CoV, and MERS) are potent at inducing disease in humans (beta coronaviruses) and harbor an untranslated region (5" UTR) and open reading frame (ORF1A, ORF1B) (blue box). These regions encode non structural proteins; $S$ box in blue encodes surface glycoproteins; $E$ box in red encodes envelope; $M$ box encodes membrane proteins; nucleocapsid proteins are encoded through $\mathrm{N}$ box flanked at the end. Similarly, box 3 and 8 (in SARSCoV-2), and $8 \mathrm{a}$ (in SARS-CoV) represent genome variations. 


\section{CONVALESCENT PLASMA AS A PROMISING OPTION FOR THE TREATMENT OF COVID-19 INFECTION}

Considering the outbreak of SARS-CoV-2 virus worldwide which potently induced COVID-19 infections, many research institutions and medical professionals around the world are still trying to seek suitable treatment options ${ }^{69}$. Infected elderly patients are receiving oxygenation, while severely infected people are receiving extracorporeal oxygenation to treat the corona virus induced disease ${ }^{24,70}$. Moreover, convalescent plasma isolated from people who have recovered from COVID-19 infection has been proven as a promising therapeutic option ${ }^{70}$. Similar investigations have suggested that following infection with COVID-19, the patient's body develops immunity at around 10-14 day after infection. Thus, administration of convalescent plasma should be considered effective 28,69 . In addition, to reduce viremia, it is promising to administer convalescent plasma at early stage of disease ${ }^{28}$. Subsequent investigations are now focused on whether concurrent administration of convalescent plasma with other antiviral drugs may increase therapeutic efficacy. Similar inculcations have already revealed that co-administration of steroids, convalescent plasma, and oxygen therapy may reduce the production of antiviral antibodies $^{28}$. Studies have demonstrated that frequent use of anti-steroids should be prohibited, while convalescent plasma should be tested to determine if efficacy is improved $^{69-71}$.

\section{RECENT CHALLENGES IN THE TREATMENT AGAINST SARS-COV-2}

In spite of substantial progress in the treatment modalities against SARS-CoV-2, there are still many countries that are experiencing challenges and concerns about therapies ${ }^{53}$. Some experimental inculcations have revealed the persistence of SARS-CoV2 in stool samples of infected patients. Detailed investigations are needed to better decipher if fecal/oral route could trigger dissemination of SARS-CoV-2 as this remains unclear $^{72}$. Likewise, experimental investigations during previous SARS-CoV and MERS-CoV outbreaks have shown that the virus can survive over inanimate objects and environments for a long period; further detailed investigations into SARS-CoV-2 persistence in the environment is greatly warranted ${ }^{72}$. Moreover, it remains unclear how efficient disinfectants are at reducing the risk of being infected with SARS-CoV-2; this area of study still requires attention and investigation ${ }^{73}$. Likewise, some experimental interventions have revealed the efficacy of Remdesivir alone to treat corona viruses; however, some cases have reported that co-administration of Remdesivir with chloroquine is effective ${ }^{27,54}$. Thus, detailed experimental investigations are required to solve this ambiguity. Most importantly, several studies revealed that $43 \%$ of patients suffered from fever and $15.7 \%$ suffered from pneumonia; detailed clarification and epidemiological investigations are needed to address asymptomatic carriers $^{74}$. Likewise, subsequent studies are needed to decipher the timely updates in therapeutic interventions, particularly in the context of cytokine milieu, which is lacking and requires collective attention $^{46}$.

\section{ONGOING STRATEGIES USED IN THE COVID-19 EPIDEMIC ESPECIALLY IN PAKISTAN}

Since there is no vaccine available against COVID19 , the prevention against the disease will remain the focus of strategy ${ }^{75}$. The primary goal should be to slow down the transmission of the virus in order to reduce the associated illnesses and deaths ${ }^{55}$. Likewise, potential ways that government and health authorities should be working in close and coordinated proximity to control the SARS-CoV-2 pandemic is a matter of utmost concern and still requires strict implementation of laws. To mitigate the mortality ratio, people in developing countries, especially, could avoid negligence and irresponsiveness when following strict strategies implemented by healthcare authorities. Thus, this prevents the chance for rapid human-human transmission and spread in communities. Therefore, each government must work together with the relevant health authorities to implement strict measures, including strict adherence to SOPs and core public health strategies, in order to control person-to-person transmission. Such strategies include identification, quarantine measures, strict individual testing, and clinical care for all cases ${ }^{76}$.

Furthermore, tracing and quarantine of all contacts should be a part of all national COVID-19 responses ${ }^{77}$. Such strategy has been successfully demonstrated in places like Wuhan, China, and has been practiced in Pakistan, as well as recognized and implemented by other countries like Germany, Vietnam and India. The actions taken by the respective governments include a range of measures in the field of public health as well as social measures to contain the spread of virus. The measures include limiting person-to-person interaction, enforcing physical and 
social distancing, and restricting movement. Since the emergence of the first case, governments have been effectively containing the virus. The containment measures include engaging communities both at individual and societal levels, providing information on how to protect oneself and others, interpreting scientific information into simplified messages, and encouraging the sharing of information at individual levels; all of these are fundamental to stop the risk of spreading.

\section{CONCLUSION}

In this review, we summarized the ongoing therapeutic interventions to treat SARS-CoV-2, key morphological features, genome variations, immunogenomics, and current challenges in treatment. Furthermore, we illustrated the current ongoing managerial strategies to manage the SARS-CoV-2 pandemic, especially in Pakistan. These revelations could lend future support for the discovering of more effective therapeutic modalities for COVID-19.

\section{ABBREVIATIONS}

APCs: antigen presenting cells

LPV, RTV: Liponavir / Ritonavir

MADG-5: melanoma differentiation gene-5

MAVS: mitochondria conceived antiviral protein

MCS: macrophage collecting syndrome

MERS: middle east respiratory syndrome

PAMPs: pathogen associated molecular patterns.

RIG-1: retinoic acid inducible gene 1

SARS-CoV: Severe acute respiratory syndrome

SARS-CoV-2: severe acute respiratory syndrome corona virus- 2

\section{ACKNOWLEDGMENTS}

The authors acknowledge the institute of Microbiology, and department of pathology, University of agriculture Faisalabad, Pakistan.

\section{AUTHOR'S CONTRIBUTIONS}

Kabeer Haneef (K.H), Muhammad Umer Asghar (M.U.A) and Ashiq Ali (A.A) are the leading authors. All these authors made substantial contributions to conception, design, acquisition of data, analysis and interpretation of data; actively contribute in drafting the article and critically provide final approval of the version to be published; and agree to be accountable for all aspects of the work.

\section{FUNDING}

This research did not receive any specific grant from funding agencies in the public, commercial, or notfor-profit sectors.

\section{AVAILABILITY OF DATA AND MATERIALS}

Not applicable.

\section{ETHICS APPROVAL AND CONSENT TO PARTICIPATE}

Not applicable.

\section{CONSENT FOR PUBLICATION}

Not applicable.

\section{COMPETING INTERESTS}

The authors declare that they have no competing interests.

\section{REFERENCES}

1. Anand K, Palm GJ, Mesters JR, Siddell SG, Ziebuhr J, Hilgenfeld R. Structure of coronavirus main proteinase reveals combination of a chymotrypsin fold with an extra $\alpha$-helical domain. EMBO J [Internet]. 2002;21(13):3213-3224. PMID: 12093723. Available from: https://doi.org/10.1093/emboj/cdf327.

2. Siddell SG, Anderson R, Cavanagh D, Fujiwara K, Klenk HD, Macnaughton MR, et al. Coronaviridae 1. 1983;189:181-189. PMID: 6654644. Available from: https://doi.org/10.1159/ 000149390 .

3. Zhong NS, Zheng BJ, Li YM, Poon LLM, Xie ZH, Chan KH, et al. Epidemiology and cause of severe acute respiratory syndrome (SARS) in Guangdong, People's Republic of China, in February, 2003. Lancet [Internet]. 2003;362(9393):1353-1358. Available from: http://www.sciencedirect.com/science/article/ pii/S0140673603146302.

4. Yang $Y$, Peng F, Wang R, Guan K, Jiang T, Xu G, et al. The deadly coronaviruses: The 2003 SARS pandemic and the 2020 novel coronavirus epidemic in China. J Autoimmun [Internet]. 2020;109:102434. PMID: 32423578. Available from: http://www.sciencedirect.com/science/article/pii/ S0896841120300470.

5. Ashour HM, Elkhatib WF, Rahman MM, Elshabrawy HA. Insights into the recent 2019 novel coronavirus (Sars-coV-2) in light of past human coronavirus outbreaks. Pathogens. 2020;9(3):1-15. PMID: 32143502. Available from: https://doi. org/10.3390/pathogens 9030186 .

6. Assiri A, McGeer A, Perl TM, Price CS, Al Rabeeah AA, Cummings DAT, et al. Hospital outbreak of middle east respiratory syndrome coronavirus. N Engl J Med. 2013;369(5):407416. PMID: 23782161. Available from: https://doi.org/10.1056/ NEJMoa1306742.

7. Lee J. Better understanding on MERS Corona virus outbreak in Korea. J Korean Med Sci. 2015;30(7):835-836. PMID: 26130942. Available from: https://doi.org/10.3346/jkms.2015. 30.7.835.

8. Kim Y, Cheon S, Min CK, Sohn KM, Kang YJ, Cha YJ, et al. Spread of Mutant Middle East Respiratory Syndrome Coronavirus with Reduced Affinity to Human CD26 during the South Korean Outbreak. Buchmeier MJ, editor MBio [Internet]. 2016;7(2):e00019-e00016. PMID: 26933050. Available from: https://doi.org/10.1128/mBio.00019-16; http://mbio.asm. org/content/7/2/e00019-16.abstract.

9. Hemida MG, Chu DKW, Poon LLM, Perera RAPM, Alhammadi $\mathrm{MA}, \mathrm{Ng} \mathrm{HY}$, et al. Mers coronavirus in dromedary camel herd, Saudi Arabia. Emerg Infect Dis. 2014;20(7):1231-1234. PMID: 24964193. Available from: https://doi.org/10.3201/eid2007. 140571. 
10. Prompetchara E, Ketloy C, Palaga T. Immune responses in COVID-19 and potential vaccines: Lessons learned from SARS and MERS epidemic. Asian Pacific J Allergy Immunol. 2020;38(1):1-9.

11. Pera A, Campos C, López N, Hassouneh F, Alonso C, Tarazona $\mathrm{R}$, et al. Immunosenescence: Implications for response to infection and vaccination in older people. Maturitas [Internet]. 2015;82(1):50-55. Available from: http://www.sciencedirect. com/science/article/pii/S0378512215006751.

12. Liuzzi AR, McLaren JE, Price DA, Eberl M. Early innate responses to pathogens: pattern recognition by unconventional human T-cells. Curr Opin Immunol [Internet]. 2015;36:31-37. PMID: 26182978. Available from: https://doi.org/10.1016/j.coi.2015.06.002;http://www. sciencedirect.com/science/article/pii/S0952791515000837.

13. Finlay BB, McFadden G. Anti-Immunology: Evasion of the Host Immune System by Bacterial and Viral Pathogens. Cell [Internet]. 2006;124(4):767-782. PMID: 16497587. Available from: https://doi.org/10.1016/j.cell.2006.01.034;http://www sciencedirect.com/science/article/pii/S0092867406001322.

14. Flajnik MF, Pasquier L. Evolution of innate and adaptive immunity: can we draw a line? Trends Immunol [Internet]. 2004;25(12):640-644. PMID: 15530832. Available from: https://doi.org/10.1016/j.it.2004.10.001;http://www. sciencedirect.com/science/article/pii/S1471490604002972.

15. Iwasaki A, Medzhitov R. Regulation of Adaptive Immunity by the Innate Immune System. Science (80- ) [Internet];327(5963):291. PMID: 20075244. Available from: https://doi.org/10.1126/science.1183021;http://science. sciencemag.org/content/327/5963/291.abstract.

16. Heesters BA, Poel CE, Das A, Carroll MC. Antigen Presentation to $B$ Cells. Trends Immunol [Internet] 2016;;37(12):844-854. PMID: 27793570. Available from: https://doi.org/10.1016/j.it.2016.10.003; http://www. sciencedirect.com/science/article/pii/S147149061630151X.

17. Batista FD, Harwood NE. The who, how and where of antigen presentation to B cells. Nat Rev Immunol [Internet]. 2009;9(1):15-27. PMID: 19079135. Available from: https: //doi.org/10.1038/nri2454.

18. Stroynowski I. Molecules Related to Class-I Major Histocompatibility Complex Antigens. Annu Rev Immunol. 1990;8(1):501-530. PMID: 2188672. Available from: https: //doi.org/10.1146/annurev.iy.08.040190.002441.

19. J BP, P P. Structure, function, and diversity of class I major histocompatibility complex molecules. Annu Rev Biochem. 1990;1990(59):253-288. Available from: 10.1146/annurev.bi. 59.070190 .001345 .

20. Yewdell JW, Hill AB. Viral interference with antigen presentation. Nat Immunol [Internet]. 2002;3(11):1019-1025. PMID: 12407410. Available from: https://doi.org/10.1038/ni11021019.

21. Schuren $A B C$, Costa Al, Wiertz EJHJ. Recent advances in viral evasion of the MHC Class I processing pathway. Curr Opin Immunol [Internet]. 2016;40:43-50. PMID: 27065088. Available from: https://doi.org/10.1016/j.coi.2016.02.007; http://www. sciencedirect.com/science/article/pii/S0952791516300073.

22. Tahir QM, Alqahtani SM, Alamri MA, Chen LL. Structural basis of SARS-CoV-2 3CLpro and anti-COVID-19 drug discovery from medicinal plants. J Pharm Anal [Internet]. 2020;Available from: https://doi.org/10.20944/preprints202002. 0193.v1;http://www.sciencedirect.com/science/article/pii/ S2095177920301271.

23. Sallard E, Lescure FX, Yazdanpanah Y, Mentre F, PeifferSmadja N. Type 1 interferons as a potential treatment against COVID-19. Antiviral Res [Internet]. 2020:178:104791. PMID: 32275914. Available from: https://doi.org/10.1016/j.antiviral.2020.104791;http://www. sciencedirect.com/science/article/pii/S0166354220302059.

24. Guo YR, Cao QD, Hong ZS, Tan YY, Chen SD, Jin HJ, et al. The origin, transmission and clinical therapies on coronavirus disease 2019 (COVID-19) outbreak- A n update on the status. Mil Med Res. 2020;7(1):1-10. PMID: 32169119. Available from: https://doi.org/10.1186/s40779-020-00240-0.

25. Cao $Y$, Deng $Q$, Dai S. Remdesivir for severe acute respiratory syndrome coronavirus 2 causing COVID-19: An evaluation of the evidence. Travel Med Infect Dis [Internet]. 2020;p. 101647. PMID: 32247927. Available from: https://doi.org/10.1016/j.tmaid.2020.101647; http://www. sciencedirect.com/science/article/pii/S1477893920301162.

26. Wang Y, Zhang D, Du G, Du R, Zhao J, Jin Y, et al. Remdesivir in adults with severe COVID-19: a randomised, doubleblind, placebo-controlled, multicentre trial. Lancet [Internet]. 2020;395(10236):1569-1578. Available from: http://www. sciencedirect.com/science/article/pii/S0140673620310229.

27. Wang M, Cao R, Zhang L, Yang X, Liu J, Xu M, et al. Remdesivir and chloroquine effectively inhibit the recently emerged novel coronavirus (2019-nCoV) in vitro. Cell Res. 2020;30(3):269-271. PMID: 32020029. Available from: https: //doi.org/10.1038/s41422-020-0282-0.

28. Duan K, Liu B, Li C, Zhang H, Yu T, Qu J, et al. Effectiveness of convalescent plasma therapy in severe COVID-19 patients. Proc Natl Acad Sci U S A. 2020;117(17):9490-9496. PMID: 32253318. Available from: https://doi.org/10.1073/pnas. 2004168117.

29. Tanne JH. Covid-19: FDA approves use of convalescent plasma to treat critically ill patients. BMJ. 2020;368:m1256. PMID: 32217555. Available from: https://doi.org/10.1136/bmj. m1256.

30. Wu JT, Leung K, Bushman M, Kishore N, Niehus R, Salazar PM, et al. Estimating clinical severity of COVID-19 from the transmission dynamics in Wuhan, China. Nat Med [Internet] 2020;26(4):506-510. PMID: 32284616. Available from: https: //doi.org/10.1038/s41591-020-0822-7.

31. Kannan S, Shaik Syed Ali P, Sheeza A, Hemalatha K. COVID-19 (Novel Coronavirus 2019) - recent trends. Eur Rev Med Pharmacol Sci. 2020;24(4):2006-2011.

32. Mohan C, Kumar V, Tokas T, Singh T, Saini M, Singh D. Evaluation of SARS \& COVID-19 Pandemic with Prevention and Hygiene Action Plan. 2020;7:228-231.

33. Sohrabi C, Alsafi Z, O'Neill N, Khan M, Kerwan A, Al-Jabir A, et al. World Health Organization declares global emergency: A review of the 2019 novel coronavirus (COVID-19). Int J Surg [Internet]. 2020;76:71-76. PMID: 32305321. Available from: https://doi.org/10.1016/j.ijsu.2020.03.036; http://www. sciencedirect.com/science/article/pii/S1743919120301977.

34. Sun J, He WT, Wang L, Lai A, Ji X, Zhai $X$, et al. COVID-19: Epidemiology, Evolution, and CrossDisciplinary Perspectives. Trends Mol Med [Internet]. 2020;26(5):483-495. PMID: 32359479. Available from: https://doi.org/10.1016/j.molmed.2020.02.008; http://www. sciencedirect.com/science/article/pii/S1471491420300654.

35. Koyama S, Ishii KJ, Coban C, Akira S. Innate immune response to viral infection. Cytokine [Internet]. 2008;43(3):336-341. PMID: 18694646. Available from: https://doi.org/10.1016/j.cyto.2008.07.009; http://www. sciencedirect.com/science/article/pii/S1043466608002214.

36. Bergmann CC, Yao Q, Ho CK, Buckwold SL. Flanking residues alter antigenicity and immunogenicity of multi-unit CTL epitopes. J Immunol [Internet]. 1996;157(8):3242 $-3249 . \quad$ Available from: http://www.jimmunol.org/content/157/8/3242.abstract.

37. Li X, Geng $M$, Peng $Y$, Meng L, Lu S. Molecular immune pathogenesis and diagnosis of COVID-19. J Pharm Anal [Internet]. 2020;10(2):102-108. PMID: 32282863. Available from: http://www.sciencedirect.com/science/article/pii/ S2095177920302045https://doi.org/10.1016/j.jpha.2020.03.001.

38. Thankam FG, Agrawal DK. Molecular chronicles of cytokine burst in COVID-19 patients with cardiovascular diseases. J Thorac Cardiovasc Surg [Internet]. 2020;Available from: https://doi.org/10.1016/j.jtcvs.2020.05.083; http://www. sciencedirect.com/science/article/pii/S0022522320313192.

39. Flür K, Allam R, Zecher D, Kulkarni OP, Lichtnekert J, Schwarz $M$, et al. Viral RNA Induces Type I Interferon-Dependent 
Cytokine Release and Cell Death in Mesangial Cells via Melanoma-Differentiation-Associated Gene-5: Implications for Viral Infection-Associated Glomerulonephritis. Am J Pathol [Internet]. 2009;175(5):2014-2022. PMID: 19850889. Available from: http://www.sciencedirect.com/science/article/ pii/S0002944010607110https://doi.org/10.2353/ajpath.2009. 080585.

40. Merad M, Martin JC. Pathological inflammation in patients with COVID-19: a key role for monocytes and macrophages. Nat Rev Immunol [Internet]. 2020;20(6):355-362. PMID: 32376901. Available from: https://doi.org/10.1038/s41577020-0331-4;http://dx.doi.org/10.1038/s41577-020-0331-4.

41. Mogensen TH, Paludan SR. Molecular Pathways in VirusInduced Cytokine Production. Microbiol Mol Biol Rev. 2001;65(1):131-150. PMID: 11238989. Available from: https: //doi.org/10.1128/MMBR.65.1.131-150.2001.

42. Marchant A, Appay V, Van Der Sande M, Dulphy N, Liesnard $C$, Kidd M, et al. Mature CD8+ T lymphocyte response to viral infection during fetal life. J Clin Invest. 2003;111(11):17471755. PMID: 12782677. Available from: https://doi.org/10. 1172/JCI200317470.

43. McGonagle D, Sharif K, O'Regan A, Bridgewood C. The Role of Cytokines including Interleukin-6 in COVID19 induced Pneumonia and Macrophage Activation Syndrome-Like Disease. Autoimmun Rev [Internet]. 2020;19(6):102537. PMID: 32251717. Available from: https://doi.org/10.1016/j.autrev.2020.102537; http://www. sciencedirect.com/science/article/pii/S1568997220300926.

44. Hui KPY, Cheung MC, Perera RAPM, Ng KC, Bui CHT, Ho JCW, et al. Tropism, replication competence, and innate immune responses of the coronavirus SARS-CoV-2 in human respiratory tract and conjunctiva: an analysis in ex-vivo and in-vitro cultures. Lancet Respir Med [Internet]. 2020;8(7):687-695. Available from: http://www.sciencedirect.com/science/article/ pii/S2213260020301934.

45. Zhang C, Wu Z, Li JW, Zhao H, Wang GQ. Cytokine release syndrome in severe COVID-19: interleukin-6 receptor antagonist tocilizumab may be the key to reduce mortality. Int J Antimicrob Agents [Internet]. 2020;55(5):105954. PMID: 32234467. Available from: https://doi.org/10.1016/j.ijantimicag.2020.105954;http://www. sciencedirect.com/science/article/pii/S0924857920301047.

46. Moore JB, June $\mathrm{CH}$. Cytokine release syndrome in severe COVID-19. Science (80- ) [Internet]. 2020;368(6490):473 -474. PMID: $32303591 . \quad$ Available from: https://doi.org/10.1126/science.abb8925;http: //science.sciencemag.org/content/368/6490/473.abstract.

47. Holshue ML, DeBolt C, Lindquist S, Lofy KH, Wiesman J, Bruce $\mathrm{H}$, et al. First case of 2019 novel coronavirus in the United States. N Engl J Med. 2020;382(10):929-936. PMID: 32004427. Available from: https://doi.org/10.1056/NEJMoa2001191.

48. Sheahan TP, Sims AC, Leist SR, Schäfer A, Won J, Brown AJ, et al. Comparative therapeutic efficacy of remdesivir and combination lopinavir, ritonavir, and interferon beta against MERSCoV. Nat Commun [Internet]. 2020;11(1). PMID: 31924756. Available from: https://doi.org/10.1038/s41467-019-13940-6.

49. Zhang W, Zhao Y, Zhang F, Wang Q, Li T, Liu Z, et al. The use of anti-inflammatory drugs in the treatment of people with severe coronavirus disease 2019 (COVID-19): The Perspectives of clinical immunologists from China. Clin Immunol [Internet]. 2020;214:108393. PMID: 32222466. Available from: https://doi.org/10.1016/j.clim.2020.108393;http://www. sciencedirect.com/science/article/pii/S1521661620301984.

50. Tian X, Li C, Huang A, Xia S, Lu S, Shi Z, et al. Potent binding of 2019 novel coronavirus spike protein by a SARS coronavirusspecific human monoclonal antibody. Emerg Microbes Infect. 2020;9(1):382-385. PMID: 32065055. Available from: https: //doi.org/10.1080/22221751.2020.1729069.

51. Liu C, Zhou Q, Li Y, Garner L V, Watkins SP, Carter LJ, et al. Research and Development on Therapeutic Agents and Vaccines for COVID-19 and Related Human Coronavirus Diseases. ACS Cent Sci [Internet]. 2020;6(3):315-331. PMID: 32226821. Avail- able from: https://doi.org/10.1021/acscentsci.0c00272.

52. Cohen J. Vaccine designers take first shots at COVID-19. Science (80-) [Internet]. 2020;368(6486):14-16. PMID: 32241928. Available from: https://doi.org/10.1126/science.368.6486;http: //science.sciencemag.org/content/368/6486/14.abstract.

53. Galluccio F, Ergonenc T, Garcia Martos A, Allam AES, PérezHerrero M, Aguilar R, et al. Treatment algorithm for COVID19: a multidisciplinary point of view. Clin Rheumatol. 2020;p. 2077-2084. PMID: 32472459. Available from: https://doi.org/ 10.1007/s10067-020-05179-0.

54. Costanzo M, De Giglio MAR, Roviello GN. SARS CoV2: Recent Reports on Antiviral Therapies Based on Lopinavir/Ritonavir, Darunavir/Umifenovir, Hydroxychloroquine, Remdesivir, Favipiravir and Other Drugs for the Treatment of the New Coronavirus. Curr Med Chem. 2020;27(00). PMID: 32297571. Available from: https://doi.org/10.2174/0929867327666200416131117.

55. Wu Z, McGoogan JM. Characteristics of and Important Lessons from the Coronavirus Disease 2019 (COVID-19) Outbreak in China: Summary of a Report of 72314 Cases from the Chinese Center for Disease Control and Prevention. JAMA - J Am Med Assoc. 2020;323(13):1239-1242. PMID: 32091533. Available from: https://doi.org/10.1001/jama.2020.2648.

56. Colson P, Rolain JM, Lagier JC, Brouqui P, Raoult D. Chloroquine and hydroxychloroquine as available weapons to fight COVID-19. Int J Antimicrob Agents [Internet]. 2020;55(4):105932. PMID: 32145363. Available from: https://doi.org/10.1016/j.ijantimicag.2020.105932.

57. Chen C, Huang J, Cheng Z, Wu J, Chen S, Zhang Y, et al. Favipiravir versus Arbidol for COVID-19: A Randomized Clinical Trial. medRxiv. 2020;Available from: https://doi.org/10.1101/2020. 03.17.20037432.

58. Lian N, Xie H, Lin S, Huang J, Zhao J, Lin Q. Umifenovir treatment is not associated with improved outcomes in patients with coronavirus disease 2019: a retrospective study. Clinical Microbiology and Infection. 2020;26(2020):917-921. Available from: https://doi.org/10.1016/j.cmi.2020.04.026.

59. Cai Q, Yang M, Liu D, Chen J, Shu D, Xia J, et al. Experimental treatment with favipiravir for COVID-19: an open-label control study. Engineering. 2020;p. Article in press. PMID: 32346491. Available from: 10.1016/j.eng.2020.03.007.

60. Cao B, Wang Y, Wen D, Liu W, Wang J, Fan G, et al. A trial of lopinavir-ritonavir in adults hospitalized with severe Covid-19. New England Journal of Medicine. 2020;382(19):1787-1799. Available from: 10.1056/NEJMoa2001282.

61. Ferner RE, Aronson JK. Chloroquine and hydroxychloroquine in covid-19. BMJ . 2020;369:m1432. Available from: https:// doi.org/10.1136/bmj.m1432.

62. Gautret P, Lagier JC, Parola P, Meddeb L, Mailhe M, Doudier $B$, et al. Hydroxychloroquine and azithromycin as a treatment of COVID-19: results of an open-label non-randomized clinical trial. International journal of antimicrobial agents. 2020;56(1):105949. Available from: https://doi.org/10.1016/j. ijantimicag.2020.105949.

63. Elfiky AA. Ribavirin, Remdesivir, Sofosbuvir, Galidesivir, and Tenofovir against SARS-CoV-2 RNA dependent RNA polymerase (RdRp): A molecular docking study. Life sciences. 2020;253(2020):117592. PMID: 32222463. Available from: 10.1016/j.lfs.2020.117592.

64. Taber LH, Knight V, Gilbert BE, McClung HW, Wilson SZ, Norton $\mathrm{HJ}$, et al. Ribavirin aerosol treatment of bronchiolitis associated with respiratory syncytial virus infection in infants. Pediatrics. 1983;72(5):613-618. PMID: 6356005.

65. Ceraolo C, Giorgi FM. Genomic variance of the 2019-nCoV coronavirus. J Med Virol [Internet]. 2020;92(5):522-528. PMID: 32027036. Available from: https://doi.org/10.1002/jmv.25700.

66. Wu A, Peng $Y$, Huang B, Ding $X$, Wang $X$, Niu $P$, et al. Genome Composition and Divergence of the Novel Coronavirus (2019-nCoV) Originating in China. Cell Host Microbe [Internet]. 2020;27(3):325-328. PMID: 32035028. Available from: https://doi.org/10.1016/j.chom.2020.02.001;http://www. 
sciencedirect.com/science/article/pii/S193131282030072X.

67. Li B, Si HR, Zhu Y, Yang XL, Anderson DE, Shi ZL, et al. Discovery of Bat Coronaviruses through Surveillance and Probe CaptureBased Next-Generation Sequencing. mSphere. 2020;5(1):111. PMID: 31996413 . Available from: https://doi.org/10.1128/ mSphere.00807-19.

68. Wan Y, Shang J, Graham R, Baric RS, Li F. Receptor Recognition by the Novel Coronavirus from Wuhan: an Analysis Based on Decade-Long Structural Studies of SARS Coronavirus. Gallagher T, editor J Virol [Internet]. 2020;94(7):e00127-e00120. PMID: 31996437. Available from: https://doi.org/10.1128/JVI. 00127-20;http://jvi.asm.org/content/94/7/e00127-20.abstract.

69. Ye M, Fu D, Ren Y, Wang F, Wang D, Zhang F, et al. Treatment with convalescent plasma for COVID-19 patients in Wuhan, China. J Med Virol [Internet];PMID: 32293713. Available from: https://doi.org/10.1002/jmv.25882.

70. Chen L, Xiong J, Bao L, Shi Y. Convalescent plasma as a potential therapy for COVID-19. Lancet Infect Dis [Internet]. 2020;20(4):398-400. Available from: https://doi.org/10.1016/ S1473-3099(20)30141-9.

71. Duan K, Liu B, Li C, Zhang H, Yu T, Qu J, et al. Effectiveness of convalescent plasma therapy in severe COVID-19 patients. Proc Natl Acad Sci [Internet]. 2020;117(17):9490 -9496. Available from: http://www.pnas.org/content/117/17/9490.abstract.

72. Lai CC, Shih TP, Ko WC, Tang HJ, Hsueh PR. Severe acute respiratory syndrome coronavirus 2 (SARS-CoV-2) and coronavirus disease-2019 (COVID-19): The epidemic and the challenges. Int J Antimicrob Agents [Internet].
2020;55(3):105924. PMID: 32081636. Available from: https://doi.org/10.1016/j.ijantimicag.2020.105924; http://www. sciencedirect.com/science/article/pii/S0924857920300674.

73. Kampf G, Todt D, Pfaender S, Steinmann E. Persistence of coronaviruses on inanimate surfaces and their inactivation with biocidal agents. J Hosp Infect [Internet]. 2020;104(3):246-251. PMID: 32035997. Available from: https://doi.org/10.1016/j.jhin.2020.01.022;http://www. sciencedirect.com/science/article/pii/S0195670120300463.

74. Guan W, Ni Z, Hu Y, Liang W, Ou C, He J, et al. Clinical characteristics of 2019 novel coronavirus infection in China. medRxiv [Internet]. 2020;Available from: http://medrxiv.org/content/ early/2020/02/09/2020.02.06.20020974.abstract.

75. Arabi YM, Fowler R, Hayden FG. Critical care management of adults with community-acquired severe respiratory viral infection. Intensive Care Med [Internet]. 2020;46(2):315-328. PMID: 32040667 . Available from: https://doi.org/10.1007/ s00134-020-05943-5.

76. Anderson RM, Heesterbeek $H$, Klinkenberg D, Hollingsworth TD. How will country-based mitigation measures influence the course of the COVID-19 epidemic? Lancet 2020;395(10228):931-934. Available from: https://doi.org/10. 1016/S0140-6736(20)30567-5.

77. Getaneh Y, Yizengaw A, Adane S, Zealiyas K, Abate Z, Leulseged $S$, et al. Global lessons and Potential strategies in combating COVID-19 pandemic in Ethiopia: Systematic Review. medRxiv [Internet]. 2020;Available from: http://medrxiv. org/content/early/2020/05/26/2020.05.23.20111062.abstract. 